\section{B A Institute of \\ YK Business Administration \\ 六下 \\ Karachi \\ Leadership and Ideas for Tomorrow}

Article 6

Volume 4 Issue 1 January-June 2009

$1-1-2009$

\title{
Customer perception of the commercial banks' services in Kano Metropolis
}

Ahmed Audu Maiyaki

Bayero Univerty, Kano, Nigeria

Follow this and additional works at: https://ir.iba.edu.pk/businessreview

Part of the Finance and Financial Management Commons

(c) (i)

This work is licensed under a Creative Commons Attribution 4.0 International License.

\section{Recommended Citation}

Maiyaki, A. A. (2009). Customer perception of the commercial banks' services in Kano Metropolis. Business Review, 4(1), 115-132. Retrieved from https://doi.org/10.54784/1990-6587.1168

This article is brought to you by iRepository for open access under the Creative Commons Attribution 4.0 License and is available at https://ir.iba.edu.pk/businessreview/vol4/iss1/6. For more information, please contact irepository@iba.edu.pk. 


\title{
ARTICLE
}

\section{Customer Perception of the Commercial Banks' Services in Kano Metropolis}

\author{
Ahmed Audu Maiyaki \\ Bayero Univerty, Kano, Nigeria
}

\subsection{INTRODUCTION}

It is a general belief that business is changing and will continue to change the way we work and live in the twenty- first century. For instance, technology shrinks time and space, customers can be anywhere in the globe and they can transact business at anytime of the day. The business environment in the present time is practically undergoing a major revolution in the way customers buy, shop, and decide to come back or to take their business elsewhere. Companies are increasingly realising that the balance of power is shifting from sellers to buyers. The customers need exactly what they want, at the right time and place they want it, with a high specification and at the lowest possible price. In addition, businesses must make customers feel special or else they will take their money to another business that can provide all what customers want (LeBoeuf, 1987).

All these developments are as a result of the fact that, today's customer is better educated and better informed, and has more choices than ever before. In the global business, geographic distance between buyers and sellers is irrelevant.

The service industry is growing and dominating world economy. According to UK office of statistics, the service industry can be categorised into financial, transport, retail and personal service (Jick, 1999). The service sector comprises a wide range of companies including banks and insurance companies. Now that the service sector employs more and more people, there has been compelling interest in services in many parts of the world and in different functional areas.

Nigerian commercial banks had been sleeping with respect to delivering excellent customer service until the advent of the so called 'new generation' banks in the early 1990s. One interesting thing is that, the coming up of the 'new generation' banks in the early 1990s, revolutionized the banking sector. Prior to this period, there was not much competition among the banks, and consequently, the customer service was very poor. The situation was so bad, to the extent that customers going to the bank either to deposit or withdraw their money would waste that day on the queue. The arm- chair banking was the order of the day; whether banks' staff look for customers or not, they would come naturally. However, with the emergence of the 'new generation' banks, the trend of competition and customer service has changed entirely. The slogan 'customer is a king' became popular in the banking industry. 
Marketing departments and customer service units were created in almost all the banks. Arm-chair banking became out-dated, as banks were seen all around on the streets running after customers. According to Idowu et al (2002), the increased demand for customer deposits resulted due to the fact that Nigerian banks, especially the new generation banks, have realized the imperative of good and prompt customer service. Proximity to the bank is no longer the issue: safety and the level of service (with regard to quality, speed and efficiency) has become the major imperative. Customer service is the key-word in this highly competitive environment. The only way to win and keep customers in this new millennium is to give them the most value for their money as they perceived it. Quality and a competitive price no longer guarantees success, it is merely a ticket to enter the race. Delivering superior service gives a business the winner's edge.

Few would argue against the importance of customer satisfaction being essential for customer loyalty within banking industry. However, to achieve customer satisfaction, a superior level of customer service and customer orientation is required (Bick et al, 2004). In addition, delivering offerings which comprise a competitive bundle of benefits or value to the customer is seen as crucial to an organization's ability to compete effectively in a particular market (Devlin, 2000). In their study, Bick et al (2004) found that a major difference existed between customer perceptions of the services they were receiving from their banks and their expectations of those services in South Africa.

The purpose of this paper is to examine the perceptions of banks' customers regarding services delivered by commercial banks in Kano metropolis. Hence, the following research questions were raised with the hope of answering them at the end of the study:

RQ 1 How is the service delivered by commercial banks is perceived by their customers and does it meet the expectation of their customers?

RQ 2 Is there an inverse correlation between the need of the customers for direct contact and improved electronic banking?

RQ 3 Is there a perception that a particular commercial bank is delivering more value/service than the other banks?

\subsection{RESEARCH METHODOLOGY}

Descriptive survey design is adopted for this study because there is no need to control the variables in the research. Although preliminary interviews with the target respondents were not conducted; but only served them with structured questionnaires which made the bulk of the research quantitative, and concentrated on information from banking customers. 


\subsubsection{POPULATION AND SAMPLE}

The population of the study comprises of all the customers of commercial banks who reside in Kano metropolis. The population constitutes working professionals and students that are active customers of these banks. These are people who would normally patronize the retail and personalized banking services in Kano. A convenience sampling technique was used. Those who completed and returned the questionnaire comprise the sample of the study. Out of the 200 questionnaires distributed, 115 were duly completed and returned.

\subsubsection{RESEARCH INSTRUMENT}

In order to test the perceptions and expectations of banks customers within the framework of the value disciplines, a questionnaire with four sections was designed. Section A captured demographic information for the purpose of describing the sample. Section B was designed to measure customer perceptions of the value being delivered by their banks, and to measure whether or not they were willing to forego direct personal contact for the benefit of improved electronic banking. Section $\mathrm{C}$ was designed to measure customer expectations of the value delivered by commercial banks. Section D was designed to measure the extent to which commercial banking customers approve or disapprove marketing promises.

\subsubsection{DATA ANALYSIS}

A total of 115 questionnaires were completed and returned. This represented a response rate of $57.5 \%$. An additional five questionnaires were received from customers of first inland Bank, and two from customers of Zenith after the cut-off date. These were not included in the sample. The data from the completed questionnaires were analysed using descriptive statistics specifically using simple percentages and tables.

\subsection{LITERATURE REVIEW}

\subsubsection{INTRODUCTION}

This part presents a review of existing literature related to the study. In view of the nature of the research topic, the review centers on: customer value; customer perception and customer satisfaction.

\subsubsection{CUSTOMER VALUE}

In this section of the paper, relevant materials have been synthesized and reviewed. Customer value is created when the perception of benefits received from a 
transaction exceed the costs of ownership (Christopher, 1996). This can be presented thus:

$$
\text { Customer value }=\frac{\text { Perception of benefits }}{\text { Total cost of ownership }}
$$

The marketing task is to find ways to enhance customer value by improving the perceived benefits and/or reducing the total cost of ownership. Both the numerator and the denominator of this ratio should be measured relative to competitive offers. Total cost of ownership rather than price is used here because, in most transactions, there will be costs other than price involved. In business - to - business markets, as buyers become more sophisticated, the total cost of ownership can be a critical element in the purchase decision (Ellram, 1993).

The concept of customer value is of equal importance in consumer marketing as it is in business - to - business environments. Again, according to Christopher (1996), to deliver superior customer value, the marketer must clearly define and communicate a 'value proposition', which is recognized by the target market as a better proposition than that presented by the competitors. It should also be recognized that in most markets there will be different value segments but that to be successful in any one of them, the customer value ratio must be seen to be superior to competitive offers.

\subsubsection{CUSTOMER PERCEPTION}

Schiffman and Kanuk (2004: 158) defined perception as the process by which an individual selects, organizes, and interprets stimuli into a meaningful and coherent picture of the world. In the other words, perception could be described as 'how people see the world around them'. Two individuals may be exposed to the same stimuli under the same apparent conditions, but how each person recognizes, selects, organizes, and interprets these stimuli is a highly individual process based on each persons needs, values, and expectations. Hence, customers interpret what they hear or see in many unique ways (LeBoeuf, 1988; Daffy, 2001). What one customer views as delightful could be seen as just average by another. Every consumer has a worldview that is already formed and which affects the product you want to sell.

According to Godin (2005), marketer should not try to change someone's worldview. Do not try to use facts to prove your case and insist they change their biases. Instead, identify a population with a certain worldview and frame a marketing communication in terms of that worldview.

Perception has a strategic implication for marketers; this is because customers make decisions based on what they perceive rather than on the basis of objective reality. Just as individuals have perceived images of themselves, they also have perceived images of products and brands. The perceived image of a product or service is 
probably more important than its actual physical characteristics (Schiffman and Kanuk, 2004). Products or services that are perceived favourably have a much better chance of being purchased than products or services with unclear or unfavourable image. It is very important for businesses to know their customers very closely for this will enable them to deliver the most desired products and/or services to the customers. The reason why customers patronize is logical from their point of view. Consequently, understanding customers derives from this fundamental premise. Everybody is unique, as they have individual pressures and criteria for making a purchase decisions (Fox, undated). Customer perceptions of service are determined by reliability, responsiveness, assurance, empathy, and tangibles, plus "intangible feel"; hence they should be properly managed (Daffy, 2001 and Piercy, 1995).

In view of the above; banks' customers for instance, perceive the quality of services they receive differently. However, it should be noted that it is more difficult for consumers to evaluate the quality of services than the quality of products. This is because of certain distinctive features that are inherent in services: intangibility; variability; perishability and inseparability. To overcome the difficulty that consumers normally face in comparing competing services side - by - side as they do with competing products, consumers rely on surrogate cues (i.e. extrinsic cues) to evaluate service quality.

\subsubsection{CUSTOMER SATISFACTION}

Satisfaction is a person's feelings of pleasure as a result of comparing a product perceived outcome in relation to his or her expectations. Consequently, if the performance exceeds the expectation, the customer is delighted. If the outcome equals the expectation, the customer is satisfied. But if the product performance falls bellow the expectation, then the customer is dissatisfied (Kotler and Keller, 2006:144)

Customer satisfaction is very important in shaping the customer perception favourably towards offerings, and in fact, is central to organisations' objectives. General management gurus - One of the earliest of the modern management gurus was, and is, Peter Drucker, who was writing nearly 40 years ago about the central purpose of the business being to "create a customer" (Drucker, 1958 in Piercy, 1995). In the same vein, the pursuit of excellence - perhaps the most widely-read management books of all time were "In Search of Excellence" and "Passion for Excellence", where lessons from what were believed to be the most "excellent" and "successful" companies in the world were associated with principles such as "getting close to the customer", and using measured customer satisfaction as a management tool (Piercy, 1995).

With commercial banking, the competitiveness of the providers' offerings can be expected to affect a customer's overall satisfaction and ongoing patronage. Research 
has shown that location is a major determinant choice (Anderson et al, 1976 and Laroche \& Taylor, 1988). Another determinant of bank choice is competitive interest rates (Laroche and Taylor, 1988). Customer satisfaction is likely to be influenced by the perceived competitiveness of interest rates.

Customer complaint handling is a major reason why customers often switch service providers when it is unsatisfactorily resolved (Hart et al, 1990). When customers face a problem, they may respond by exiting (switching to a new supplier), voicing (attempting to remedy the problem by complaining) or loyalty (staying with the supplier in anticipating that 'things will get better') (Hirschman, 1970).

To date, little empirical evidence exists as to how customer product usage patterns impact on customer satisfaction. Customers or segments with different needs or usage patterns may have different determinants of customer satisfaction. In the retail banking sector, customers who use particular products (e.g. loans or mortgages) may focus on service features, such as competitive interest rates, more than customers who do not hold these products. Thus, the determinants of customer satisfaction towards the service provider may vary depending on customer or segment characteristics.

\section{COMMERCIAL BANK SERVICES}

Significant portion of the services delivered by commercial banks in Kano is retail banking. The retail banking means banking services that are supplied by banks to individual customers (Bick, Brown and Abratt; 2004). It excluded all forms of business banking and related financial products, and private banking. Retail banking have been generally classified under the following categories: transaction and payment products, such as cheque accounts and debit cards; investment products, such as saving accounts, fixed deposits and unit trusts; credit and borrowing products, such as credit cards, home loans, overdrafts and car finance; and financial planning products such as retirement annuity plans and education policies. Based on observed practices, most of the commercial banks in Nigeria offer the aforementioned assorted services.

According to Bick, Brown and Abratt (2004), retail banking is a mature industry and banks offer similar services/products. Marketing strategies in the maturity stage include consideration of market modification, product modification or changing the marketing mix.

Some confusion surrounded the concept of a 'product' in financial services. Retail banks referred to a cheque account or a credit card as a product. Actually, it is service that facilitates the exchange of value between a seller and a buyer. Devlin and Ennew (1997) see Bick et al (2004) distinguished between services features, e.g. a cheque account, and service support such as a bank teller or an Automated Teller 
Machine. Again, Devlin and Ennew (1997) see Bick et al (2004) noted that, the intangible nature of financial services makes it difficult to envisage the use of specific services features as the basis for establishing competitive advantage. Services cannot be patented, so service features generally can be easily copied.

Another confusion existed as to whether internet or telephone banking constitutes a product or part of the delivery mechanism of the bank. However, for the purpose of this paper, all forms of electronic banking are classified as part of the distribution channels and not products.

Obviously, service employees should not be left out in the discussion of service delivery. This is because of the inherent nature of service- inseparability; the simultaneous production and consumption nature of service. In high contact service industries, where the service is inseparable from the person providing it, the interaction between customers and service workers offers a potential means by which a firm can achieve true customer loyalty. Many researchers such as Barnes, (1995); Beatty, Mayer, Coleman, Reynolds, and Lee, (1996); Gremler and Gwinner, (1998); Gwinner, Gremler, and Bitner, (1998) (see Bove and Johnson, 2000) have maintained that customer relationships with service workers are influential in the development of true customer loyalty to a service organisation, particularly in situations of ongoing service where there is a high level of interaction required by the participants. However, there is a lack of empirical evidence to support this and little attention has been given to the mechanism by which this could be achieved (Gwinner, Gremler, and Bitner, (1998)).

Given that employees are necessary in the service delivery, by implication, they determine the perception- positive or negative- a customer will hold on the service of a company. Consequently, the person who delivers the service is of key importance to both the customer he serves and the employer he represents. To the customer, he is in fact part of the product. Thus, his ability and willingness to satisfy, his manner and appearance, all play a part in determining how satisfied the customer is with the service encounter. On the other hand, to the employer, those delivering the service can make or break the organization (Mudie and Cottam, 1993). Similarly, Hammond (2003) suggests that organizations should keep its people happy and they will make money for the firm. A happy team of motivated employees, pulling together and having fun with customers, brimming with ideas and enthusiasm, can build huge performance improvements.

Excellent service on the part of frontline employees is never a co-incidence, rather it is usually the result of a careful selection, plenty of customer service training, and a well-designed reward system. This suggests the need to properly screen and recruit the frontline staff. 


\section{DATA PRESENTATION AND ANALYSIS}

The data collected were tabulated in tables, a simple percentage ratio calculated to show the degree of responses made by the selected respondents. The tables are followed by relevant interpretation.

Q1. Customers perceived that value of some kind is being delivered by banks

\begin{tabular}{|l|l|l|}
\hline Responses & Respondents & Percentage \\
\hline Strongly agreed & 95 & $83 \%$ \\
\hline Agreed & 20 & $17 \%$ \\
\hline Disagreed & 0 & $0 \%$ \\
\hline Total & 115 & $100 \%$ \\
\hline
\end{tabular}

Source: field survey, March 2007

From the above table, customers certainly feel that some value of one kind or the other is being delivered by banks as 95 respondents strongly agreed to that. However, none of the respondent believes that banks do not deliver value of some sort.

Q2. The perceived value delivered differ between banks

\begin{tabular}{|l|l|l|}
\hline Responses & Respondents & Percentage \\
\hline Strongly agreed & 89 & $77 \%$ \\
\hline Agreed & 17 & $15 \%$ \\
\hline Disagreed & 09 & $8 \%$ \\
\hline Total & 115 & $100 \%$ \\
\hline
\end{tabular}

Source: field survey, March 2007

It can be seen from the above table that most of the respondents strongly agreed that the value deliver by banks differ significantly. Only $9 \%$ disagreed with the statement.

Q3. Please indicate the level of your satisfaction with the value delivered by banks products and services.

\begin{tabular}{|l|l|l|}
\hline Responses & Respondents & Percentage \\
\hline Highly satisfied & 75 & $65 \%$ \\
\hline Just satisfied & 34 & $30 \%$ \\
\hline Not satisfied & 06 & $5 \%$ \\
\hline Total & 115 & $100 \%$ \\
\hline
\end{tabular}

Source: field survey, March 2007

While $5 \%$ of the respondents are not satisfied with the products and services rendered by banks, the majority of the respondents think otherwise. 65 percent and 30 percent of the respondents are highly satisfied and just satisfied respectively. 
Q4. What do you feel about the charges of your bank?

\begin{tabular}{|l|l|l|}
\hline Responses & Respondents & Percentage \\
\hline Outrageous & 13 & $11 \%$ \\
\hline High & 32 & $28 \%$ \\
\hline Reasonable & 70 & $61 \%$ \\
\hline Total & 115 & $100 \%$ \\
\hline
\end{tabular}

Source: field survey, March 2007

Majority of the bank customers, that participated in the research, were comfortable with their banks' charges; as $61 \%$ percent of the respondents felt that their various banks' charges are reasonable, and only 13 respondents (representing $11 \%$ )felt that their bank charges are outrageous.

Q4. You get fair value for the banks charges you pay?

\begin{tabular}{|l|l|l|}
\hline Responses & Respondents & Percentages \\
\hline Agreed & 45 & $39 \%$ \\
\hline Neutral & 38 & $33 \%$ \\
\hline Disagreed & 32 & $28 \%$ \\
\hline Total & 115 & $100 \%$ \\
\hline
\end{tabular}

Source: field survey, March 2007

From the above figures, although $39 \%$ of the respondents believed that they derived fair value for the charges they pay, a fairly large number of them (28\%) disagreed with the statement. Also relatively large number of the respondents felt indifferent about the statement.

Q5. Does your bank engage in electronic banking?

\begin{tabular}{|l|l|l|}
\hline Responses & Respondents & Percentage \\
\hline Yes & 97 & $84 \%$ \\
\hline No & 04 & $4 \%$ \\
\hline No idea & 14 & $12 \%$ \\
\hline Total & 115 & $100 \%$ \\
\hline
\end{tabular}

Source: field survey, March 2007

More than three-quarter of the respondents said that their respective banks engage in electronic banking. Only four respondents representing $4 \%$ said that their banks do not engage in the electronic banking.

Q6. If yes, to what extent does your bank use electronic banking in delivering services?

\begin{tabular}{|l|l|l|}
\hline Responses & Respondents & Percentage \\
\hline High & 38 & $33 \%$ \\
\hline Moderate & 43 & $37 \%$ \\
\hline Low & 34 & $30 \%$ \\
\hline Total & 115 & $100 \%$ \\
\hline
\end{tabular}


Source: field survey, March 2007

While 33 percent of the respondents are of the view that their banks utilize electronic banking to a large extent, 43 respondents (representing 37\%) felt that their banks moderately use electronic banking. On the other hand, $30 \%$ of the respondents said that the usage of electronic in their banks is low. This shows that till now there are substantial number of banks that are yet to start electronic bank operations.

Q7. You might decrease the level of direct contact as a trade-off for improved electronic banking

\begin{tabular}{|l|l|l|}
\hline Responses & Respondents & Percentage \\
\hline Agreed & 74 & $64 \%$ \\
\hline Neutral & 27 & $24 \%$ \\
\hline disagreed & 14 & $12 \%$ \\
\hline Total & 115 & $100 \%$ \\
\hline
\end{tabular}

Source: field survey, March 2007

The above table indicates that quite a large number of customers prefer electronic banking than the usual conventional banking. 74 respondents (representing 64\%) agreed that they are ready to reduce direct contact because of improved electronic banking. This means, both the banks and customer could benefit from the electronic banking. More often customers undergo inconveniences in direct checking transaction; and the banks, on the other hand, must have make arrangements of more cashiers/tellers at peak period.

Q8. Your bank's electronic banking facilities allow you to perform transaction easily

\begin{tabular}{|l|l|l|}
\hline Responses & Respondents & Percentage \\
\hline Agreed & 65 & $57 \%$ \\
\hline Neutral & 35 & $30 \%$ \\
\hline disagreed & 15 & $13 \%$ \\
\hline Total & 115 & $100 \%$ \\
\hline
\end{tabular}

Source: field survey, March 2007

Only $13 \%$ of the respondents disagreed with the statement that electronic banking allows easy banking transaction and more than $50 \%$ of the respondents believed that electronic banking facilitates easy banking transaction. This corroborate the previous statement that electronic banking has simplified and made banking transaction more convenient than ever before.

Q9. What is the level of reliability of your bank's electronic facilities?

\begin{tabular}{|l|l|l|}
\hline Responses & Respondents & Percentage \\
\hline Highly reliable & 19 & $16 \%$ \\
\hline Just reliable & 33 & $29 \%$ \\
\hline Moderately reliable & 48 & $42 \%$ \\
\hline Unreliable & 15 & $13 \%$ \\
\hline Total & 115 & $100 \%$ \\
\hline
\end{tabular}


Source: field survey, March 2007

While $16 \%$ and $13 \%$ of the respondents felt that the bank electronic facilities are highly reliable and unreliable respectively; a relatively large number of the respondents (42\%) believed that the banks electronic facilities are moderately reliable. This presumably is because of the fact that Nigerian banks are just adopting electronic banking and they do not possess much experience and therefore, some failures are bound to occur.

Q11. Indicate the level of your satisfaction with electronic banking system

\begin{tabular}{|l|l|l|}
\hline Responses & Respondents & Percentage \\
\hline Highly satisfied & 77 & $67 \%$ \\
\hline Just satisfied & 38 & $33 \%$ \\
\hline Not satisfied & 0 & $0 \%$ \\
\hline Total & 115 & $100 \%$ \\
\hline
\end{tabular}

Source: field survey, March 2007

Although Nigerian banks face some difficulties in operating electronically, majority of the people participating in the research (67\%) were highly satisfied with the banks electronic banking and none was dissatisfied with it.

Q13. Competition affects service delivery among banks

\begin{tabular}{|l|l|l|}
\hline Responses & Respondents & Percentage \\
\hline Agreed & 105 & $91 \%$ \\
\hline Neutral & 10 & $9 \%$ \\
\hline disagreed & 0 & $0 \%$ \\
\hline
\end{tabular}

Source: field survey, March 2007

Over $90 \%$ of the respondents agreed that competition in the banking industry influence service delivery, while $9 \%$ felt indifferent and none disagreed with the statement. This means that level of competition affects the nature of service delivery to a large extent.

Q14. Your bank offer better online product/services than other banks

\begin{tabular}{|l|l|l|}
\hline Responses & Respondents & Percentage \\
\hline Very sure & 14 & $12 \%$ \\
\hline Sure & 38 & $33 \%$ \\
\hline Not sure & 63 & $55 \%$ \\
\hline Total & 115 & $100 \%$ \\
\hline
\end{tabular}

Source: field survey, March 2007

The above figures show that there is variation in terms of online services/products offered by various banks. To this effect, $12 \%$ of the respondents were very sure that their online products/services surpass that of other banks, while $33 \%$ were just sure. On the other extreme, 55\% were not sure about the statement. 
Q15. How do you rate convenient location of bank as a factor in bank choice?

\begin{tabular}{|l|l|l|}
\hline Responses & Respondents & Percentage \\
\hline Very important & 88 & $77 \%$ \\
\hline important & 22 & $19 \%$ \\
\hline Not important & 5 & $4 \%$ \\
\hline Total & 115 & $100 \%$ \\
\hline
\end{tabular}

Source: field survey, March 2007

The above table shows that a convenient location of bank is a major determinant of bank choice and consequently bank patronage. While 88 respondents (representing $77 \%$ ) considered location to be a very important determinant of bank choice, only $4 \%$ of the respondents felt otherwise.

\section{CONCLUSION}

The purpose of the research was to provide satisfactory answers to the research question raised earlier on, as well as to meet the objectives of the research. In this section, the major findings with respect to the research questions and the key research objectives are summarized:

RQ1: How is the value delivered by commercial banks in Kano metropolis perceived by their customers and does it meet the expectation of the customers?

This question was answered in two parts. The first part concerns customer perceptions of the value delivered to them by commercial banks. The results were overwhelmingly positive, indicating that customer were satisfied with the services, products and level of customer service delivered by their banks.

The second aspect of the question involved customer's expectations of value. A significant leaning towards the operational excellence value resulted. This indicated that customers rated problem-free, convenient and efficient banking as the most important aspect of value. And majority of the respondents appeared to be enjoying these expectations from their various bankers.

RQ2: Is there any relationship between customer's need for direct customer contact and improved electronic banking?

The results showed that, most of the commercial banks engage in electronic banking. Although, in most of the banks, the electronic banking is just moderately reliable; still the customers preferred it against the conventional banking in the branch. They were very happy to trade off direct customer contact for the convenience of electronic banking. 
RQ3: Is there a perception that a particular commercial bank is delivering more value than the other banks?

This research revealed that customers did perceived significant difference between the values offered by various commercial banks. This is presumably because of the fact that the banks possess different experiences in the adoption of electronic banking. And, in some cases, they have different electronic banking facilities of different quality.

\section{REFERENCES}

Bick, G.; Brown, A.B. and Abratt, R. (2004), 'Customer Perceptions of the value delivered by retail banks in South Africa', International Journal of Bank Marketing, Vol. 22 No. 5, 2004

Barnes, J.G. (1997), “'Closeness, strength, and satisfaction: examining the nature of relationships between providers of financial services and their retail customers", Psychology and Marketing, Vol. 14 No. 8, pp.765-90.

Bove, L.L. and Jonhnson, L.W. (2000), 'A Customer-service Worker Relationship Model’ International Journal of Service Industry Management, Vol. 11 No.

5, 2000, pp. 491-511

Christopher, M. (1996), 'From brand value to customer value' Journal of Marketing Practices, vol. 2 No. 1, pp 55-66

Daffy, C. (2001), Once a Customer, Always a customer: How to Deliver Customer Service that Creates Customers for life, Oak Tree Press.

Ellram, L. (1993), 'Total cost of ownership: Elements and Implications', International Journal of Purchasing and Materials Management, vol. 29 No.4

Fox, H.W. (undated), Understanding Your Customers, hppt: //www.i2m.org/ftp/freepubs/6005.pdf

Godin, S. (2005), All Marketers Are Liars: The Power of Telling Authentic Stories in a Low-Trust World, Portfolio

Hart, C.W.L., Heskett, J.L. and Sasser, E.W. Jr (1990), 'The profitable art of service recovery’, Harvard Business Review, Vol. 68 No. 4, pp 148- 156

Hammond, R. (2003), Smart Retail: How to Turn Your Store into a Sales Phenomenon, Richard Pearson Prentice Hall Business, 
Website: http://tools.ashridge.org.uk/ashridge/vlrc.nsf/site/BRSmart.htm

Idowu, P.A., Alu, A.O. and Adagunodo, E.R. (2002), 'The Effect of Information Technology on the Growth of the Banking Industry in Nigeria', The Electronic Journal on Information Systems in Developing Countries, EJISDC, 10, 2, 1-8, http://www.ejisdc.org

Kotler, P. and Keller K.L. (2006), Marketing management $12^{\text {th }}$ ed, Prentice-Hall, Inc, Upper Saddle River, New Jersey USA.

Laroche, M. and Taylor, T. (1988), 'An empirical study of major major segmentation issues in retail banking', nternational Journal of Bank Marketing, Vol. 6 No.1, pp 3148

LeBoeuf, M. (1987), How to Win Customers \& Keep them for them for Life, Berkley Publishing Group, New York USA

Levesque, T. and McDougall, G.H.G. (1996), Determinants of customer satisfaction in retail banking’, International Journal of Bank Marketing,14/7, pp 12-20

Mudie, P. and Cottam A. (1993), the Management and Marketing of Services, Butterworth- Heinemann Ltd, Oxford

Piercy, N.F. (1995), Customer Satisfaction and the Internal Market: $\quad$ Marketing our customers to our employees, Journal of Marketing Practice:Applied Marketing Science, Vol. 1 No. 1, 1995, pp. 22-44. 글

Schiffman L.G. \& Kanuk L.L. (2004), Consumer Behaviour $8^{\mathrm{TH}}$ ed., Peason Education Ltd, India

\section{APPENDIX}

Q1. Customers perceived that value of some kind is being delivered by banks

\begin{tabular}{|l|l|l|}
\hline Responses & Respondents & Percentage \\
\hline Strongly agreed & & \\
\hline Agreed & & \\
\hline Disagreed & & \\
\hline Total & & \\
\hline
\end{tabular}

Q2. The perceived value delivered differ between banks

\begin{tabular}{|l|l|l|}
\hline Responses & Respondents & Percentage \\
\hline Strongly agreed & & \\
\hline Agreed & & \\
\hline
\end{tabular}




\begin{tabular}{|l|l|l|}
\hline Disagreed & & \\
\hline Total & & \\
\hline
\end{tabular}

Q3. Please indicate the level of your satisfaction with the value delivered by banks products and services.

\begin{tabular}{|l|l|l|}
\hline Responses & Respondents & Percentage \\
\hline Highly satisfied & & \\
\hline Just satisfied & & \\
\hline Not satisfied & & \\
\hline Total & & \\
\hline
\end{tabular}

Q4. What do you feel about the charges of your bank?

\begin{tabular}{|l|l|l|}
\hline Responses & Respondents & Percentage \\
\hline Outrageous & & \\
\hline High & & \\
\hline Reasonable & & \\
\hline Total & & \\
\hline
\end{tabular}

Q4. You get fair value for the banks charges you pay?

\begin{tabular}{|l|l|l|}
\hline Responses & Respondents & Percentages \\
\hline Agreed & & \\
\hline Neutral & & \\
\hline Disagreed & & \\
\hline Total & & \\
\hline
\end{tabular}

Source: field survey, March 2007

Q5. Does your bank engage in electronic banking?

\begin{tabular}{|l|l|l|}
\hline Responses & Respondents & Percentage \\
\hline Yes & & \\
\hline No & & \\
\hline No idea & & \\
\hline Total & & \\
\hline
\end{tabular}

Q6. If yes, to what extent does your bank use electronic banking in delivering services?

\begin{tabular}{|l|l|l|}
\hline Responses & Respondents & Percentage \\
\hline High & & \\
\hline Moderate & & \\
\hline Low & & \\
\hline Total & & \\
\hline
\end{tabular}


Q7. You might decrease the level of direct contact as a trade-off for improved electronic banking

\begin{tabular}{|l|l|l|}
\hline Responses & Respondents & Percentage \\
\hline Agreed & & \\
\hline Neutral & & \\
\hline disagreed & & \\
\hline Total & & \\
\hline
\end{tabular}

Q8. Your bank’s electronic banking facilities allow you to perform transaction easily

\begin{tabular}{|l|l|l|}
\hline Responses & Respondents & Percentage \\
\hline Agreed & & \\
\hline Neutral & & \\
\hline disagreed & & \\
\hline Total & & \\
\hline
\end{tabular}

Q9. What is the level of reliability of your bank's electronic facilities?

\begin{tabular}{|l|l|l|}
\hline Responses & Respondents & Percentage \\
\hline Highly reliable & & \\
\hline Just reliable & & \\
\hline Moderately reliable & & \\
\hline Unreliable & & \\
\hline Total & & \\
\hline
\end{tabular}

Q10. You benefit more from electronic banking than conventional banking

\begin{tabular}{|l|l|l|}
\hline Responses & Respondents & Percentage \\
\hline Agreed & 83 & $72 \%$ \\
\hline Neutral & 22 & $19 \%$ \\
\hline Disagreed & 10 & $9 \%$ \\
\hline Total & 115 & $100 \%$ \\
\hline
\end{tabular}

Your bank’s electronic banking transactions are secured

\begin{tabular}{|l|l|l|}
\hline Responses & Respondents & Percentage \\
\hline Agreed & & \\
\hline Neutral & & \\
\hline disagreed & & \\
\hline Total & & \\
\hline
\end{tabular}

Q11. Indicate the level of your satisfaction with electronic banking system

\begin{tabular}{|l|l|l|}
\hline Responses & Respondents & Percentage \\
\hline Highly satisfied & & \\
\hline Just satisfied & & \\
\hline Not satisfied & & \\
\hline
\end{tabular}

130 
https://ir.iba.edu.pk/businessreview/vol4/iss1/6

DOI: https://doi.org/10.54784/1990-6587.1168

Business Review - Volume 4 Number 1

January - June 2009

\begin{tabular}{|l|l|l|}
\hline Total & & \\
\hline
\end{tabular}

Q12. Your bank delivers its promise on the appointed time

\begin{tabular}{|l|l|l|}
\hline Responses & Respondents & Percentage \\
\hline Agreed & & \\
\hline Neutral & & \\
\hline disagreed & & \\
\hline Total & & \\
\hline
\end{tabular}

Q13. Competition affects service delivery among banks

\begin{tabular}{|l|l|l|}
\hline Responses & Respondents & Percentage \\
\hline Agreed & & \\
\hline Neutral & & \\
\hline disagreed & & \\
\hline
\end{tabular}

Q14. Your bank offer better online product/services than other banks

\begin{tabular}{|l|l|l|}
\hline Responses & Respondents & Percentage \\
\hline Very sure & & \\
\hline Sure & & \\
\hline Not sure & & \\
\hline Total & & \\
\hline
\end{tabular}

Q15. How do you rate convenient location of bank as a factor in bank choice

\begin{tabular}{|l|l|l|}
\hline Responses & Respondents & Percentage \\
\hline Very important & & \\
\hline important & & \\
\hline Not important & & \\
\hline Total & & \\
\hline
\end{tabular}

Q16. Indicate the level of your satisfaction with account operations in your bank

\begin{tabular}{|l|l|l|}
\hline Responses & Respondents & Percentage \\
\hline Very satisfied & & \\
\hline Just satisfied & & \\
\hline Not satisfied & & \\
\hline
\end{tabular}


https://ir.iba.edu.pk/businessreview/vol4/iss1/6

DOI: https://doi.org/10.54784/1990-6587.1168

Business Review - Volume 4 Number 1

January - June 2009

The expression, "Knowledge is power," is used by Lord Bacon; but it had its origin long before his time, in the saying of Solomon, that "a wise man is strong: yea, a man of knowledge increaseth strength.”

Socrates said that a knowledge of our own ignorance is the first step toward true knowledge. - And Coleridge said, We cannot make another comprehend our knowledge until we first comprehend his ignorance.

"Knowledge," says Bacon, "is power"; but mere knowledge is not power; it is only possibility. Action is power; and its highest manifestation is when it is directed by knowledge. - T.W. Palmer. 